Article

\title{
Potassium $\left(\mathrm{K}^{+}\right)$Starvation-Induced Oxidative Stress Triggers a General Boost of Antioxidant and NADPH-Generating Systems in the Halophyte Cakile maritima
}

\author{
Hayet Houmani ${ }^{1,2}{ }^{,}$Ahmed Debez ${ }^{2}$, Larisse de Freitas-Silva ${ }^{1}$, Chedly Abdelly ${ }^{2}$, José M. Palma ${ }^{1}$ (D) \\ and Francisco J. Corpas $1, * \mathbb{D}$
}

1 Group of Antioxidants, Free Radicals and Nitric Oxide in Biotechnology, Food and Agriculture, Department of Biochemistry, Cell and Molecular Biology of Plants, Estación Experimental del Zaidín, CSIC, Apartado 419, E-18080 Granada, Spain; houmani100@gmail.com (H.H.); larisse_bio@yahoo.com.br (L.d.F.-S.); josemanuel.palma@eez.csic.es (J.M.P.)

2 Laboratory of Extremophile Plants, Center of Biotechnology of Borj Cedria, P.O. Box 901, Hammam-Lif 2050, Tunisia; ahmed.debez@cbbc.rnrt.tn (A.D.); chedly.abdelly@cbbc.rnrt.tn (C.A.)

* Correspondence: javier.corpas@eez.csic.es

\section{check for}

updates

Citation: Houmani, H.; Debez, A.; Freitas-Silva, L.d.; Abdelly, C.; Palma, J.M.; Corpas, F.J. Potassium $\left(\mathrm{K}^{+}\right)$ Starvation-Induced Oxidative Stress Triggers a General Boost of Antioxidant and NADPH-Generating Systems in the Halophyte Cakile maritima. Antioxidants 2022, 11, 401. https://doi.org/10.3390/ antiox11020401

Academic Editor: Sang Yeol Lee

Received: 11 January 2022

Accepted: 14 February 2022

Published: 16 February 2022

Publisher's Note: MDPI stays neutral with regard to jurisdictional claims in published maps and institutional affiliations.

Copyright: (C) 2022 by the authors. Licensee MDPI, Basel, Switzerland. This article is an open access article distributed under the terms and conditions of the Creative Commons Attribution (CC BY) license (https:// creativecommons.org/licenses/by/ $4.0 /)$.

\begin{abstract}
Potassium $\left(\mathrm{K}^{+}\right)$is an essential macro-element for plant growth and development given its implication in major processes such as photosynthesis, osmoregulation, protein synthesis, and enzyme function. Using 30-day-old Cakile maritima plants as halophyte model grown under $\mathrm{K}^{+}$ deprivation for 15 days, it was analyzed at the biochemical level to determine the metabolism of reactive oxygen species (ROS), key photorespiratory enzymes, and the main NADPH-generating systems. $\mathrm{K}^{+}$starvation-induced oxidative stress was noticed by high malondialdehyde (MDA) content associated with an increase of superoxide radical $\left(\mathrm{O}_{2}{ }^{-}-\right)$in leaves from $\mathrm{K}^{+}$-deficient plants. $\mathrm{K}^{+}$ shortage led to an overall increase in the activity of hydroxypyruvate reductase (HPR) and glycolate oxidase (GOX), as well as of antioxidant enzymes catalase (CAT), those of the ascorbate-glutathione cycle, peroxidase (POX), and superoxide dismutase (SOD), and the main enzymes involved in the NADPH generation in both leaves and roots. Especially remarkable was the induction of up to seven $\mathrm{CuZn-SOD}$ isozymes in leaves due to $\mathrm{K}^{+}$deficiency. As a whole, data show that the $\mathrm{K}^{+}$starvation has associated oxidative stress that boosts a biochemical response leading to a general increase of the antioxidant and NADPH-generating systems that allow the survival of the halophyte Cakile maritima.
\end{abstract}

Keywords: ascorbate peroxidase; Cakile maritima; catalase; CuZn-SOD isozymes; halophyte; NADPisocitrate dehydrogenase; pentose phosphate pathway; oxidative stress; potassium deficiency

\section{Introduction}

Potassium is the fourth most abundant macro-element in the lithosphere $(2.5 \%)$. In a soil solution $\mathrm{K}^{+}$concentration is about 0.01 to $20 \mathrm{mM}$ [1], whereas this nutrient needs to be maintained within a range of 100-200 $\mathrm{mM}$ in the plant cell cytosol [2]. Multiple functions are ascribed to this macronutrient and have been recently reviewed [3-5]. $\mathrm{K}^{+}$availability for plants depends on the complex dynamics of the soil which are strongly influenced by root-soil interactions [6]. In soils, $\mathrm{K}^{+}$can be found as either soluble, exchangeable, fixed, or associated with minerals [7]. The release of the exchangeable form is slow and hence insufficient for plant growth and development [7]. Thus, imbalanced nutrition with $\mathrm{K}^{+}$is well known. Under $\mathrm{K}^{+}$limited conditions, impairment in photosynthetic apparatus occurs affecting notably the electron transfer chain and $\mathrm{CO}_{2}$ fixation, thus enhancing the oxygen photoreduction in chloroplasts and leading to high production of reactive oxygen species (ROS). To cope with low $\mathrm{K}^{+}$availability, plants have evolved several strategies to increase $\mathrm{K}^{+}$uptake and maintain their ROS homeostasis. In the few reports addressing plant response to $\mathrm{K}^{+}$deficiency, the modulation of the antioxidant 
enzyme systems including superoxide dismutase (SOD), catalase (CAT), and all enzymatic components of the ascorbate-glutathione cycle was described [8-11]. However, the available information on the regulation of antioxidant defense upon $\mathrm{K}^{+}$starvation mostly concerns glycophytes and crops, whereas halophytes remain poorly addressed. These kinds of plants are particularly challenged with the nutrient shortage in their natural habitats, whether direct (due to soil poverty) or indirect (caused by the salt-induced restriction of nutrient uptake) [12]. Thus, understanding the responses to nutrient (particularly potassium) deficiency in halophytes with emphasis on the regulation of antioxidant defense upon $\mathrm{K}^{+}$starvation is pertinent, as it may enable the selection of species with high antioxidant capacity and tolerance to $\mathrm{K}^{+}$deficiency.

The metabolism of ROS, which includes mechanisms of ROS generation and a set of antioxidant systems [13], keeps under control the potential ROS overproduction that can cause oxidative damages usually associated with many types of stresses, such as salinity [14], heavy metals [15,16], drought, and mechanical wounding [17]. Furthermore, NADPH is a basic indicator of cellular redox status required for cell growth, proliferation, and detoxification [18-22]. Thus, NADPH is strictly necessary by the antioxidant enzyme glutathione reductase (GR) in the ascorbate-glutathione pathway to regulate $\mathrm{H}_{2} \mathrm{O}_{2}$ content in the different subcellular compartments including cytosol, chloroplasts, mitochondria, and peroxisomes. It is also needed by the NADPH-dependent thioredoxin reductases (NTRs) in the regulation of metabolic pathways through thiol group reduction. In addition to the ferredoxin-NADP reductase (FNR) in photosynthetic cells, NADPH is mainly generated by NADP-isocitrate dehydrogenase (NADP-ICDH), NADP-malic enzyme (NADP-ME) also named NADP-malate dehydrogenase, glucose-6-phosphate dehydrogenase (G6PDH), and 6-phosphogluconate dehydrogenase (6PGDH), the latter two belonging to the oxidative part of the pentose phosphate pathway. All these enzymes are also involved in diverse, basic metabolic pathways such as carbon and nitrogen metabolisms [23-27].

Cakile maritima L. (Brassicaceae) is an annual succulent halophyte with high tolerance to osmotic constraints [28-31] which has also great potential as a nutritious crop [32]. This species is also well known for its high seed oil content (up to $40 \%$ of seed DW) [33]. The natural ecosystems for C. maritima are sandy littoral dunes, which are known for their poor nutrient composition [34]. Given its high nutrient use and absorption efficiencies [35], its aptitude to substitute $\mathrm{K}^{+}$with $\mathrm{Na}^{+}$in many biological functions, and the performance of its antioxidant system [36], C. maritima is a useful candidate to investigate halophyte responses to nutrient deficiencies in its antioxidant response. Therefore, the present study aimed at better characterizing the response of $C$. maritima to $\mathrm{K}^{+}$deficiency with special emphasis on the plant growth, the water content, the antioxidative stress response, and the nutrient status.

Overall, the data provide evidence that $\mathrm{K}^{+}$starvation provoked oxidative stress which triggers a general boost of the main antioxidant systems, and this was also accompanied by an increase in the NADPH-generating system in both roots and leaves, thus allowing the survival of C. maritima.

\section{Materials and Methods}

\subsection{Plant Material and Growth Conditions}

C. maritima seeds were cleaned with commercial sodium hypochlorite $(50 \% ; w / v)$ for $4 \mathrm{~min}$. Then they were washed five times with distilled water, and then sown in foilcovered Petri dishes containing two layers of filter paper imbibed with $15 \mathrm{~mL} \mathrm{H}_{2} \mathrm{O}$ [28]. After seven days, plantlets were hydroponically grown in half-strength Hoagland's nutrient solution $\left(2.5 \mathrm{mM} \mathrm{Ca}\left(\mathrm{NO}_{3}\right)_{2} \cdot 4 \mathrm{H}_{2} \mathrm{O}, 2.5 \mathrm{mM} \mathrm{KNO}_{3}, 0.5 \mathrm{mM} \mathrm{KH}_{2} \mathrm{PO}_{4}\right.$, and $1 \mathrm{mM}$ $\mathrm{MgSO}_{4} \cdot 7 \mathrm{H}_{2} \mathrm{O}$ for the macronutrients; and $23.2 \mu \mathrm{M} \mathrm{H}_{3} \mathrm{BO}_{3}, 4.6 \mu \mathrm{M} \mathrm{MnCl} \mathrm{Mn}_{2} \cdot 4 \mathrm{H}_{2} \mathrm{O}, 1.2 \mu \mathrm{M}$ $\mathrm{ZnSO}_{4} \cdot 7 \mathrm{H}_{2} \mathrm{O}, 0.185 \mu \mathrm{M} \mathrm{CuSO} \cdot \cdot 5 \mathrm{H}_{2} \mathrm{O}$, and $0.06 \mu \mathrm{M} \mathrm{Na} 2 \mathrm{MoO}_{4} \cdot 2 \mathrm{H}_{2} \mathrm{O}$ for the micronutrients) for an additional 7 days. Thereafter, plants were separated into two sets to study $\mathrm{K}^{+}$ deficiency: control plants were kept in the Hoagland nutrient solution, and deficient plants were cultivated after transplanting to a medium without $\mathrm{K}^{+}$. The deficiency of $\mathrm{NO}_{3}{ }^{-}$and 
$\mathrm{PO}_{4}{ }^{3-}$ in the nutrient solution was corrected by the addition of appropriate amounts of $\mathrm{NaNO}_{3}$ and $\left(\mathrm{NH}_{4}\right) \mathrm{H}_{2} \mathrm{PO}_{4}[10,37]$. The plant culture was carried out under greenhouse conditions (16 h photoperiod, $24 / 18{ }^{\circ} \mathrm{C}$ light/dark temperature; $80 \%$ relative humidity). After another 15 days, plants were harvested and separated into roots and leaves and stored at $-80{ }^{\circ} \mathrm{C}$ for biochemical assays. Figure 1 shows the experimental design to study $\mathrm{K}^{+}$deficiency in C. maritima.

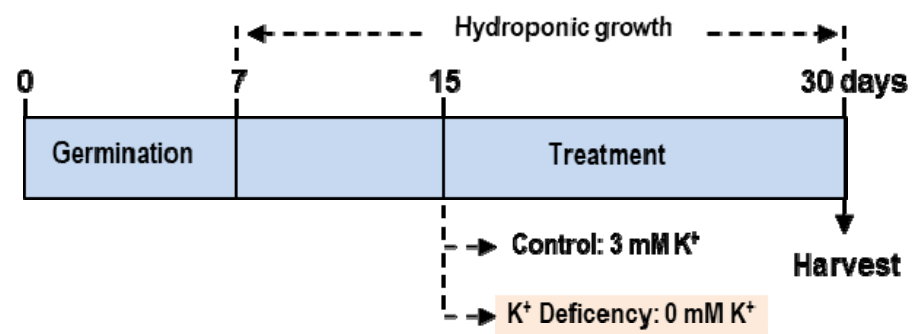

Figure 1. Experimental design to study potassium deficiency in the halophyte Cakile maritima L. Seeds were germinated in Petri dishes for 7 days. Then, the plantlets were hydroponically grown in half-strength Hoagland's nutrient solution for an additional 7 days. Thereafter, plants were separated in two lots: control (C) plants kept in the Hoagland nutrient solution containing $3 \mathrm{mM} \mathrm{K}^{+}$and deficient plants, cultivated after transplanting to a medium without $\mathrm{K}^{+}$. After 15 additional days, plants were harvested.

\subsection{Plant Crude Extracts}

Plant organs (roots and leaves) were collected and frozen in liquid $\mathrm{N}_{2}$. Then, the samples were ground to a powder in a mortar with a pestle. Two grams of the powder were suspended in a ratio $1 / 2(w / v)$ in $50 \mathrm{mM}$ Tris- $\mathrm{HCl}$ buffer $(\mathrm{pH} 7.8)$ containing $0.1 \mathrm{mM}$ EDTA, $0.02 \%(w / v)$ Triton X-100, 10\% (v/v) glycerol, 1\% $(w / v)$ polyvinylpolypyrrolidone (PVPP), and $5 \mathrm{mM}$ dithiothreitol (DTT). The crude extracts were then filtered through one layer of Miracloth and centrifuged at $27,000 \times g$ at $4{ }^{\circ} \mathrm{C}$ for $25 \mathrm{~min}$. Finally, the supernatants were collected and used for assays.

\subsection{Water Content}

Water content (WC) of each organ was calculated as the difference between the fresh $(\mathrm{FW})$ and dry (DW) weights according to the following equation $W C=(\mathrm{FW}-\mathrm{DW}) / \mathrm{DW}$. Plant material was dried for 5 days at $65^{\circ} \mathrm{C}$ on a stove.

\subsection{Potassium Content and Cellular Potassium Concentration}

To determine $\mathrm{K}$ content in leaves and roots, samples were oven-dried at $60{ }^{\circ} \mathrm{C}$ and then ground into fine powder. $\mathrm{K}$ was extracted from the obtained powder (approximately 30-60 mg) by digestion with nitric/perchloric acid, and $\mathrm{K}$ analysis was performed using atomic absorption spectrophotometry (Perkin Elmer 1100 B). Cellular K concentration, a crucial parameter for the evaluation of $\mathrm{K}^{+}$status inside the plant cell, was estimated as the ratio of $\mathrm{K}^{+}$and water contents.

\subsection{Lipid Peroxidation and Histochemical Detection of Superoxide Radical $\left(\mathrm{O}_{2}{ }^{\bullet-}\right)$ in Leaves}

Lipid peroxidation products were estimated by measuring the malondialdehyde (MDA) content through the thiobarbituric acid reactive substances (TBARS) method [38].

For the histochemical detection of $\mathrm{O}_{2}{ }^{\bullet-}$, leaves from control and $\mathrm{K}^{+}$-deficient plants were excised and vacuum-infiltrated for $5 \mathrm{~min}$ in a nitroblue tetrazolium (NBT) solution (0.5 $\mathrm{mg} \mathrm{mL}^{-1}$ in $100 \mathrm{mM}$ phosphate buffer, $\mathrm{pH}$ 6.8). After infiltration, the samples were incubated for $1 \mathrm{~h}$ at $25{ }^{\circ} \mathrm{C}$ in darkness. Then, leaves were illuminated until the appearance of dark blue spots, characteristic of blue formazan precipitates [39]. 


\subsection{Anthocyanins}

Anthocyanin content was determined according to the Gould et al. (2000) [40] method. Samples were preserved in $2 \mathrm{~mL}$ of a solution containing $\left(\mathrm{HCl} / \mathrm{H}_{2} \mathrm{O} /\right.$ methanol $)(v / v / v$; $1 / 3 / 6)$ and stored at $4{ }^{\circ} \mathrm{C}$ in the dark until the subsequent pigment extraction. The absorbance was read at 530 and $653 \mathrm{~nm}$. The following formula was used to determine the anthocyanin content:

Anthocyanins concentration $\left(\mu \mathrm{g} \mathrm{mL}^{-1}\right)=\mathrm{OD}_{530}-0.24 \cdot \mathrm{OD}_{653}$

\subsection{In-Gel Isozyme Profile Analyses of Superoxide Dismutase (SOD), Peroxidase (POX), and Ascorbate Peroxidase (APX)}

The SOD isozymes were separated by non-denaturing polyacrylamide gel electrophoresis (PAGE) on $8 \%$ acrylamide gels and visualized by a photochemical NBT reduction method [41]. The type of SOD isozymes was identified according to its sensitivity to different inhibitors, $5 \mathrm{mM} \mathrm{KCN}$ or $5 \mathrm{mM} \mathrm{H}_{2} \mathrm{O}_{2}$. CuZn-SOD is inhibited by $\mathrm{KCN}$ and $\mathrm{H}_{2} \mathrm{O}_{2}$; Fe-SOD is only inhibited by $\mathrm{H}_{2} \mathrm{O}_{2}$ while Mn-SOD is unaffected by either $\mathrm{KCN}$ or $\mathrm{H}_{2} \mathrm{O}_{2}$ [28]. The POX isozymes were separated by non-denaturing PAGE on $6 \%$ acrylamide gels and detected as previously described by [42]. Briefly, gels were incubated for $20 \mathrm{~min}$ in sodium acetate buffer $0.1 \mathrm{M}$, pH 5.5 containing 3,3-diaminobenzidine $1 \mathrm{mM}$, and $\mathrm{H}_{2} \mathrm{O}_{2}(0.03 \%)$, and brown bands appeared at the end of the reaction. APX isozymes were separated as described by [43]. Briefly, gels were prepared at $10 \%$ acrylamide and run for $30 \mathrm{~min}$ at $120 \mathrm{~V}$ before samples were loaded. Electrophoresis was conducted for $3 \mathrm{~h}\left(120 \mathrm{~V}, 4^{\circ} \mathrm{C}\right)$. Then, gels were incubated three times in $50 \mathrm{mM}$ potassium phosphate buffer, $\mathrm{pH} 7.0$, containing $2 \mathrm{mM}$ ascorbic acid for $10 \mathrm{~min}$ each, and once in $50 \mathrm{mM}$ potassium phosphate buffer, $\mathrm{pH} 7.0$, containing $4 \mathrm{mM}$ ascorbic acid and $0.5 \mu \mathrm{M} \mathrm{H}_{2} \mathrm{O}_{2}$ for $10 \mathrm{~min}$. After the last incubation, gels were rinsed twice with distilled water and equilibrated for 1-2 $\mathrm{min}$ in $50 \mathrm{mM}$ potassium phosphate buffer $\mathrm{pH}$ 7.8. The staining reaction was started by adding $50 \mathrm{mM}$ potassium phosphate buffer pH 7.8 containing $14 \mathrm{mM}$ TEMED and $2.45 \mathrm{mM}$ NBT. The reaction was stopped when the first blue bands became visible by decanting the staining solution and rinsing the gels with distilled water.

\subsection{Determination of Enzyme Activities}

Glycolate oxidase (GOX; EC 1.1.3.1) was assayed by determining the formation of the complex glyoxylate-phenylhydrazone as described previously by [44]. NADH-dependent hydroxypyruvate reductase (HPR; EC 1.1.1.2 9) was assayed according to Schwitzguébel and Siegenthaler (1984). Catalase activity (CAT; EC 1.11.1.6) was determined using the [45] method which consists of measuring the disappearance of $\mathrm{H}_{2} \mathrm{O}_{2}$ at $240 \mathrm{~nm}$. Ascorbate peroxidase (APX; EC 1.11.1.11) was determined by monitoring the initial ascorbate oxidation by $\mathrm{H}_{2} \mathrm{O}_{2}$ at $290 \mathrm{~nm}$ [46]. Monodehydroascorbate reductase (MDAR; EC 1.6.5.4) was assayed by measuring the monodehydroascorbate-dependent NADH oxidation, with monodehydroascorbate being generated by the ascorbate/ascorbate oxidase system [47]. The rate of monodehydroascorbate-independent NADH oxidation (without ascorbate and ascorbate oxidase) was subtracted from the monodehydroascorbate-dependent reaction. Glutathione reductase (GR; EC 1.6.4.2) was measured following the Edwards et al. (1990) [48] method by monitoring the NADPH oxidation at $340 \mathrm{~nm}$ coupled to the reduction of GSH (the reaction rate was corrected for the small, non-enzymatic oxidation of NADPH by glutathione disulfide, GSSG). Dehydroascorbate reductase (DHAR; EC 1.8.5.1) was determined by following the increase of ascorbate formation at $265 \mathrm{~nm}$ using $\mathrm{N}_{2}$-saturated buffer [49]. The reaction rate was corrected by the non-enzymatic reduction of dehydroascorbate by glutathione (GSH). A factor of 0.98 , to account for the small contribution to the absorbance by GSSG, was also considered.

NADP-dependent dehydrogenase (NADP-DH) activities were determined spectrophotometrically by recording the reduction of $\mathrm{NADP}^{+}$at $340 \mathrm{~nm}$. The assays were performed at $25^{\circ} \mathrm{C}$ in a reaction medium $(1 \mathrm{~mL})$ containing $50 \mathrm{mM}$ HEPES, pH 7.6, $2 \mathrm{mM} \mathrm{MgCl}{ }_{2}$, 
and $0.8 \mathrm{mM}$ NADP. The reaction was initiated by the addition of a specific substrate for each enzyme. Thus, NADP-ICDH (EC 1.1.1.42) activity was started by the addition of $10 \mathrm{mM}$ 2R,3S-isocitrate; G6PDH (EC 1.1.1.49) activity was initiated by the addition of $5 \mathrm{mM}$ glucose-6-phosphate; to determine 6PGDH (EC 1.1.1.44) activity, the substrate was $5 \mathrm{mM}$ 6-phosphogluconate was initiated; and, in the case of NADP-ME (EC 1.1.1.40) activity, the reaction was started by the addition of $1 \mathrm{mM}$ L-malate [50-52]. Protein concentration was determined using the Bio-Rad protein assay with bovine serum albumin as standard.

\subsection{Statistical Analysis}

Statistical analysis was performed using the Statgraphics program and data were analyzed by one-way ANOVA. Asterisk denotes that means are significantly different at $p<0.05$.

\section{Results}

\subsection{Effect of Potassium Starvation on C. maritima Growth Parameters}

To corroborate the potassium deficiency in the experimental design, the potassium content in roots and shoots was evaluated. Table 1 shows that in C. maritima plants grown in nutrient solutions deficient in potassium, the $\mathrm{K}^{+}$content and concentration were significantly lower in both organs (on average $86 \%$ ) in comparison to plants grown under optimal conditions.

Table 1. $\mathrm{K}^{+}$content and $\mathrm{K}^{+}$concentration $\left(\mathrm{mg} \mathrm{mL}^{-1}\right)$ in shoots and roots of $C$. maritima under optimal or limiting $\mathrm{K}^{+}$conditions. Results are the mean of at least three different experiments $\pm \mathrm{SEM}$. Asterisk indicates that values in the same row are significantly different at $p<0.05$.

\begin{tabular}{lcc}
\hline Organs & $\mathbf{3 ~} \mathbf{m M ~ K}^{+}$ & $\mathbf{0 ~} \mathbf{~ M ~ K}^{+}$ \\
\hline Shoot K content $\left(\mathrm{mg} \mathrm{g}^{-1}\right.$ dry weight $)$ & $4.05 \pm 0.14$ & $0.46 \pm 0.04^{*}$ \\
\hline Root K content $\left(\mathrm{mg} \mathrm{g}^{-1}\right.$ dry weight) & $3.89 \pm 0.57$ & $0.56 \pm 0.09$ * \\
\hline Shoot K concentration $\left(\mathrm{mg} \mathrm{mL}^{-1}\right)$ & $0.43 \pm 0.02$ & $0.065 \pm 0.003$ * \\
\hline Root K concentration $\left(\mathrm{mg} \mathrm{mL}^{-1}\right)$ & $0.29 \pm 0.02$ & $0.063 \pm 0.010^{*}$ \\
\hline
\end{tabular}

Figure 2a shows a representative picture of 30-day-old C. maritima plants grown under potassium deficiency $\left(0 \mathrm{mM} \mathrm{K}^{+}\right)$which showed a $33 \%$ decrease in plant biomass production (Figure $2 \mathrm{~b}$ ) as compared to plants cultivated on optimal conditions $\left(3 \mathrm{mM} \mathrm{K} \mathrm{K}^{+}\right.$). A 53\% reduction in leaf number was also observed under the same conditions (Figure 2c). The lack of $\mathrm{K}^{+}$in the culture medium negatively affected both leaf and root water content $(17 \%$ and $30 \%$, respectively), suggesting the induction of water stress by $\mathrm{K}^{+}$deficiency (Figure $2 \mathrm{~d}$ ). 
(a) Phenotype of C. marttlma plants and leaves
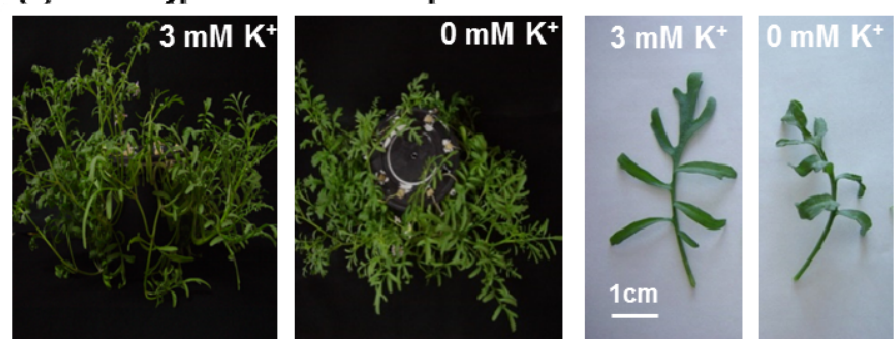

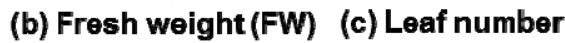

(d) Water content (WC)
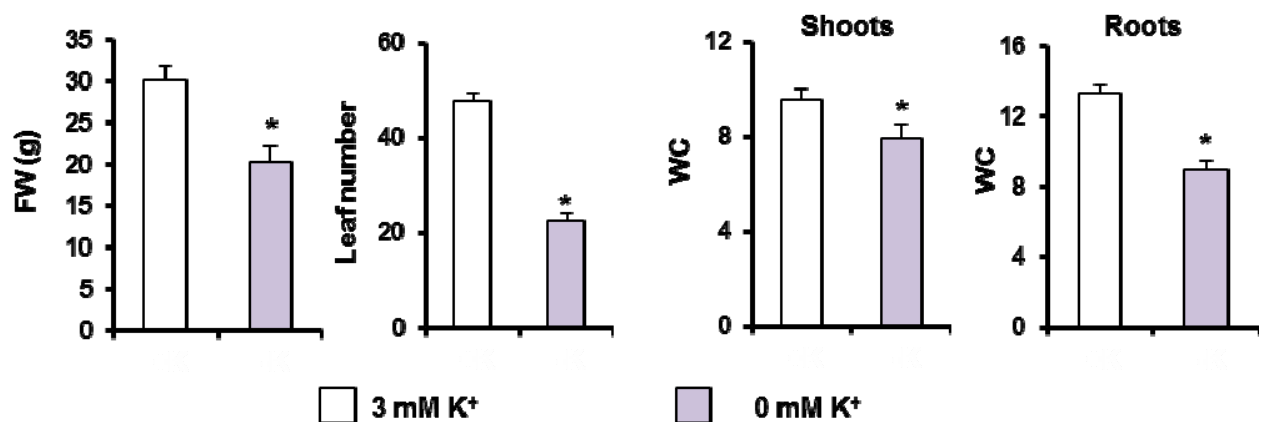

$3 \mathrm{mM} \mathrm{K}^{+}$

$0 \mathrm{mM} \mathrm{K+}$

Figure 2. Phenotype and growth attributes of 30-day-old C. maritima plants grown in the presence or absence of $\mathrm{K}^{+}$in the culture medium for 15 days. (a) Phenotype of $C$. maritima growth in the hydroponic cultivation and leaf detail. (b) Plant fresh weight (FW). (c) Leaf number per plant. (d) Shoot and root water contents (WC). Results are the mean of at least three different experiments \pm SEM. Asterisks indicate that differences between values were statistically significant at $p<0.05$.

\subsection{Metabolism of ROS and Photorespiration under $\mathrm{K}^{+}$Deficiency in C. maritima}

Lipid peroxidation, as a marker of membrane oxidative damages, and production of $\mathrm{O}_{2}{ }^{\bullet-}$ were used to evaluate the impact of ROS metabolism under $\mathrm{K}^{+}$deficiency. The in vivo production of $\mathrm{O}_{2}{ }^{--}$was assayed as the reduction and further precipitation of NBT leading to the appearance of dark spots of blue formazan in leaves from C. maritima plants subjected to $\mathrm{K}^{+}$deficiency, but not in leaves from control plants (Figure 3A). As a potential result of the accumulation of $\mathrm{O}_{2}{ }^{\bullet-}$ and dismutation to $\mathrm{H}_{2} \mathrm{O}_{2}$, oxidative damage to membrane lipids was investigated by evaluating the MDA content, the final product of lipid peroxidation. There was a significant increase in MDA content (49\%) in leaves from plants grown under $\mathrm{K}^{+}$deficiency; in roots, the MDA values remained close to the control (Figure 3B). On the other hand, the content of anthocyanins increased about $53 \%$ in leaves of C. maritima plants grown under $\mathrm{K}^{+}$deficiency (Figure 3C).

Two peroxisomal photorespiratory enzymes were also analyzed. Thus, whereas hydroxypyruvate reductase (HPR) grew about 20\% (Figure 4a), glycolate oxidase (GOX), which is considered one of the main sources of $\mathrm{H}_{2} \mathrm{O}_{2}$ in green tissues, increased 2.8-fold (Figure $4 \mathrm{~b}$ ) under $\mathrm{K}^{+}$starvation. On the other hand, catalase, the main $\mathrm{H}_{2} \mathrm{O}_{2}$-removing enzyme also located in peroxisomes, increased 1.8-fold in leaves and 1.3-fold in roots of plants grown under $\mathrm{K}^{+}$deficiency (Figure $4 \mathrm{c}$ ). 
A. Superoxide radical

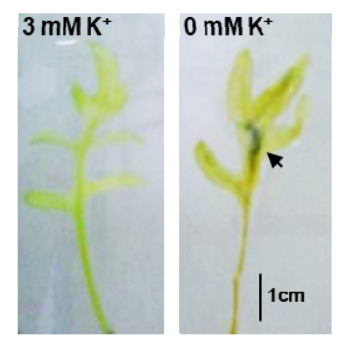

$3 \mathrm{mM} \mathrm{K}^{+}$

$0 \mathrm{mM} \mathrm{K}$

\section{B. LIpId peroxldation}
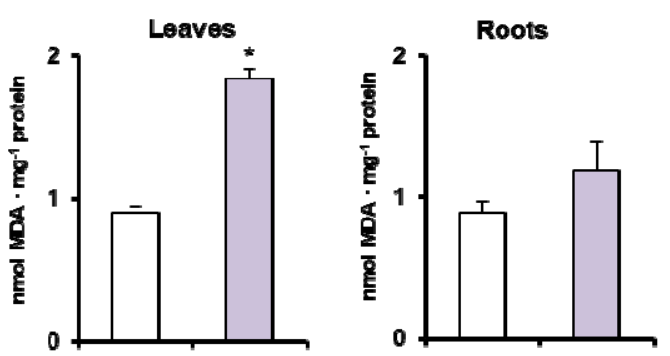

C. Leaf anthocyanin content

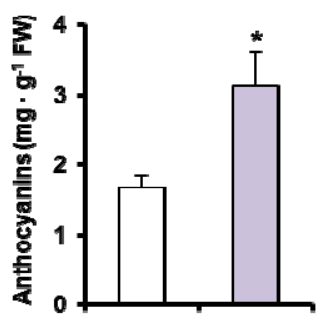

Figure 3. ROS parameters and anthocyanin content in 30-day-old C. maritima plants grown in the presence or absence of $\mathrm{K}^{+}$in the culture medium for 15 days. (A) Histochemical detection of superoxide radical with NBT staining in leaves. Arrow indicates the precipitated blue formazan product. (B) Lipid peroxidation (MDA) in leaves and roots. (C) Leaf anthocyanin content. Results are the mean of at least three different experiments \pm SEM. Asterisks indicate that differences between values were statistically significant at $p<0.05$.

$\square 3 \mathrm{mM} \mathrm{K}^{+}$

(a) Hydroxypruvate reductase

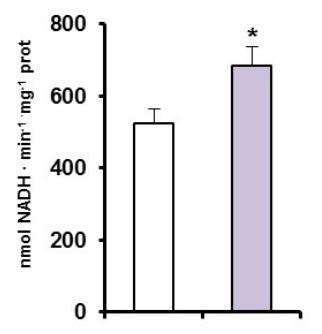

(c) Catalase

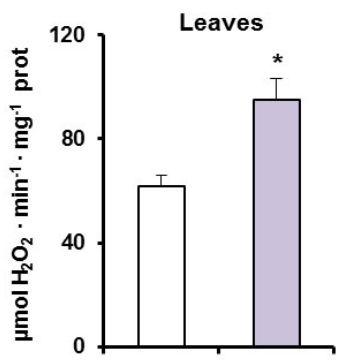

$0 \mathrm{mM} \mathrm{K}^{+}$

(b) Glycolate oxidase
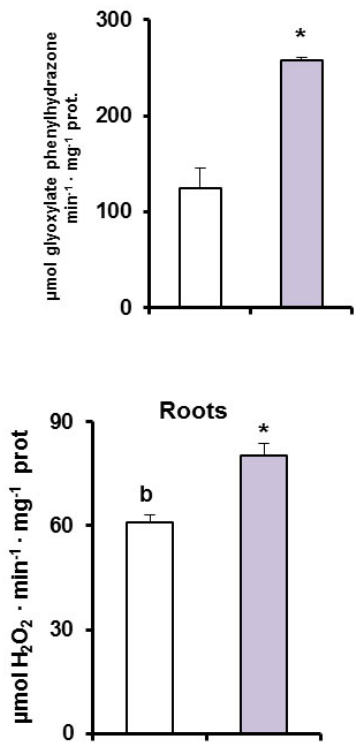

Figure 4. Activities of photorespiratoy enzymes and catalase in C. maritima plants grown in the presence or absence of $\mathrm{K}^{+}$in the culture medium for 15 days. (a) Glycolate oxidase activity. (b) Hydroxypruvate reductase activity. (c) Catalase activity. Results are the mean of three different experiments \pm SEM. Asterisks indicate that differences between values were statistically significant at $p<0.05$.

Given the importance of the ascorbate-glutathione cycle to control the cellular $\mathrm{H}_{2} \mathrm{O}_{2}$ content in coordination with catalase, the activity of its enzymatic components (APX, MDAR, DHAR, and GR) was spectrophotometrically assessed (Figure 5a-d). In general, 
the activity of these enzymes was higher in roots than in leaves, and under $\mathrm{K}^{+}$deficiency a significant increase of all these activities in both organs was found, except for MDAR in roots and DHAR in leaves that were unaffected. The data on APX activity correlates with the isozyme pattern obtained after native PAGE and specific in-gel activity staining. Two APX isozymes were detected in leaves and roots, being the most prominent isozymes in roots. Under $\mathrm{K}^{+}$deficiency, there was a slight increase of APX isozymes in both organs (Figure 6a).
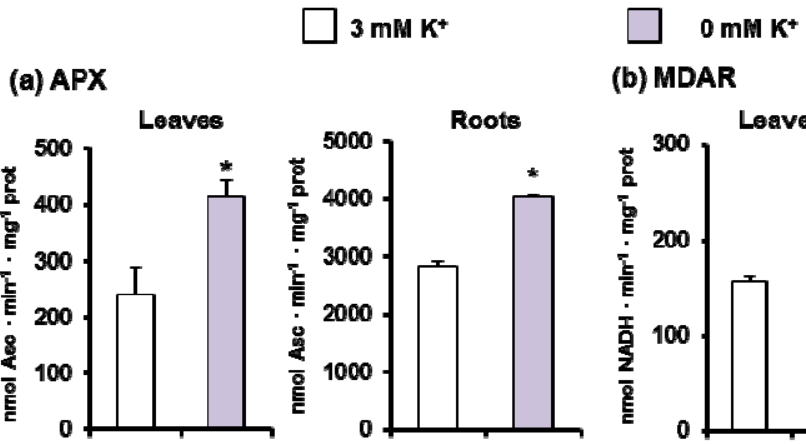

\section{(b) MDAR}
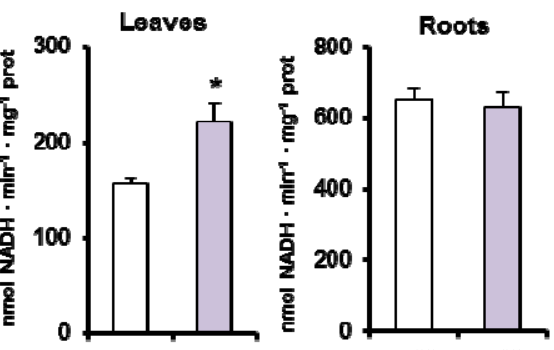

(c) DHAR
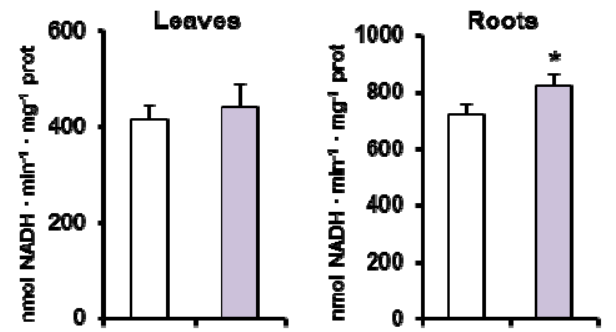

(d) GR

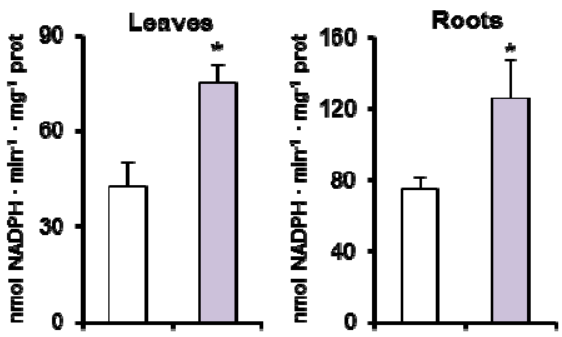

Figure 5. Ascorbate-glutathione cycle activities in leaves and roots of 30-day-old C. maritima plants grown in the presence or absence of $\mathrm{K}^{+}$in the culture medium for 15 days. (a) Ascorbate peroxidase (APX) activity. (b) Monodehydroascrobate reductase (MDAR) activity. (c) Dehydroascorbate reductase (DHAR) activity. (d) Glutathione reductase (GR) activity. Results are the mean of three different experiments \pm SEM. Asterisks indicate that differences between values were statistically significant at $p<0.05$.

The analysis of POX isozyme patterns in C. maritima revealed essentially the same profile in leaves and roots, with a total of five isozymes designated $\mathrm{I}$ to $\mathrm{V}$ according to their increased mobility in the gel, with the intensity of the bands considerably higher in roots than in leaves (Figure $6 \mathrm{~b}$ ). Under $\mathrm{K}^{+}$starvation, in leaves POX I, III, and IV increased. However, in roots there were no apparent changes due to $\mathrm{K}^{+}$deficiency, except for a slight decrease of POX V, an isozyme that was not detected in leaves.

Figure $6 \mathrm{c}$ shows the analysis of SOD isozyme activity patterns obtained after native PAGE and NBT staining of gels in both leaves and roots from C. maritima grown under optimal and low $\mathrm{K}^{+}$supply. In leaves from control plants, only a single Fe-SOD was present in crude extracts. However, under $\mathrm{K}^{+}$deficiency this isozyme was undetectable, whereas until seven $\mathrm{CuZn-SODs}$ isozymes (designated as I to VII) were induced, CuZn-SODs I to III were the most prominent. In roots, two Mn-SOD and four CuZn-SOD (I to IV) isozymes were identified, with a light activity increase under K deficiency (Figure 6c). 
(b) POX isozymes

(a) APX isozymes
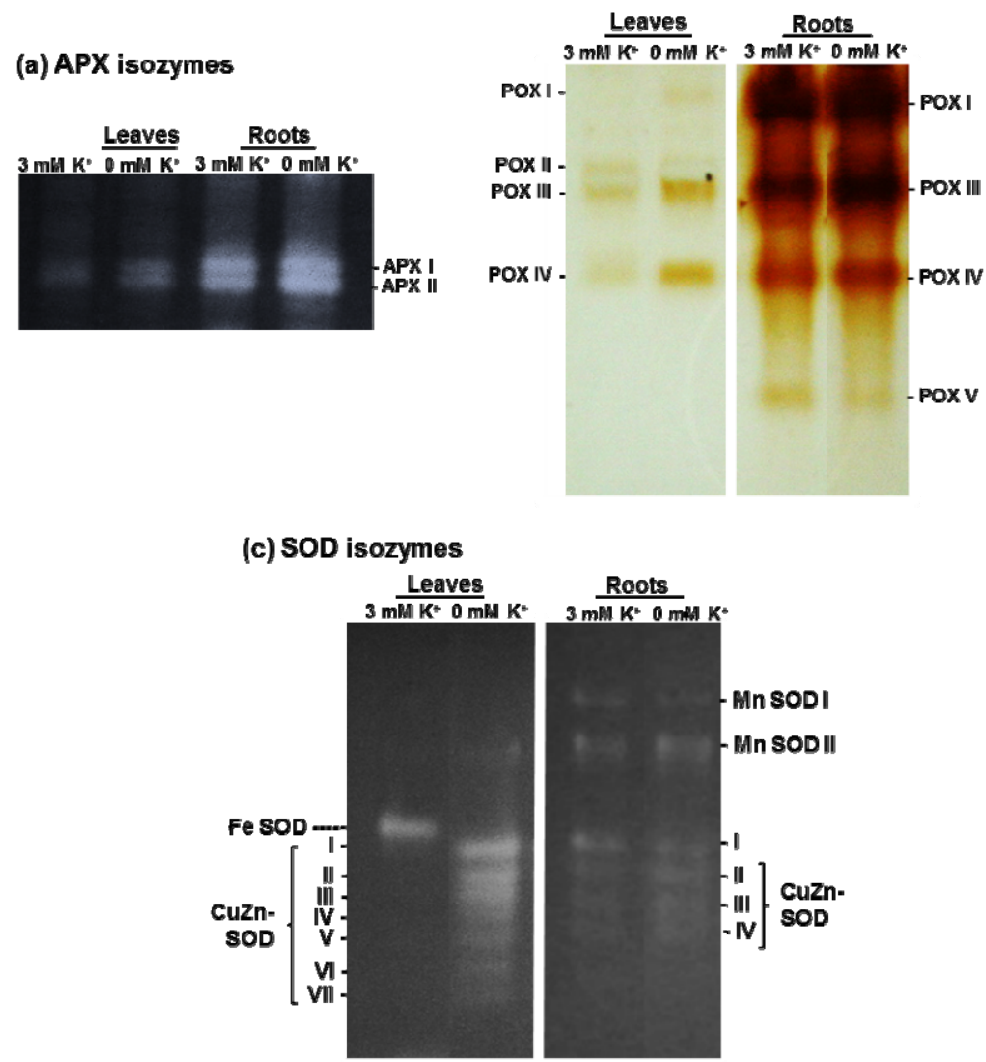

Figure 6. Analysis of APX, POX, and SOD isozymes in C. maritima plants grown in the presence or absence of $\mathrm{K}^{+}$in the culture medium for 15 days. (a) Ascorbate peroxidase (APX) isozymes (40 $\mu \mathrm{g}$ of proteins per lane). (b) Peroxidase (POX) isozymes ( $80 \mu \mathrm{g}$ of proteins per lane). (c) Superoxide dismutase (SOD) isozymes (100 and $40 \mu \mathrm{g}$ of proteins per lane were used for leaves and roots, respectively). The different isozymes were separated by native PAGE ( $8 \%$ for SOD, $10 \%$ for APX, and $6 \%$ for POX).

\subsection{Metabolism of NADP-Dehydrogenases under $K^{+}$Deficiency in C. maritima}

Figure 7 illustrates the activity of the four main NADPH-generating enzymes, NADPICDH (Figure 7a), NADP-ME (Figure 7b), and the two enzymes of the oxidative pentose phosphate pathway, G6PDH and 6PGDH (Figure 7c,d, respectively). In general, the activity of these NADP-dehydrogenases was higher in roots than in leaves, and under $\mathrm{K}^{+}$deficiency all activities underwent a significant increase in both organs.

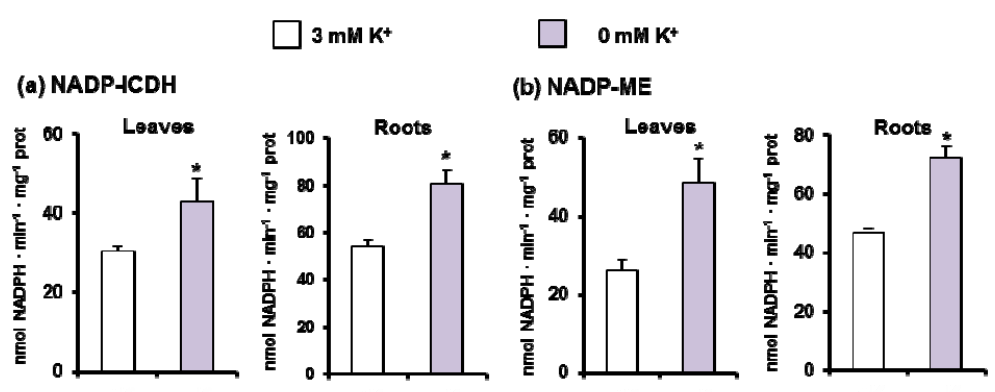

Figure 7. Cont. 
(c) G6PDH

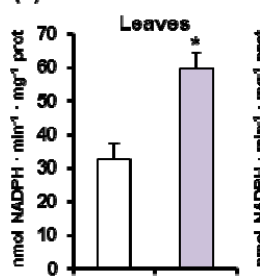

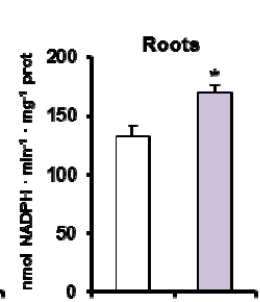

(d) 6PGDH

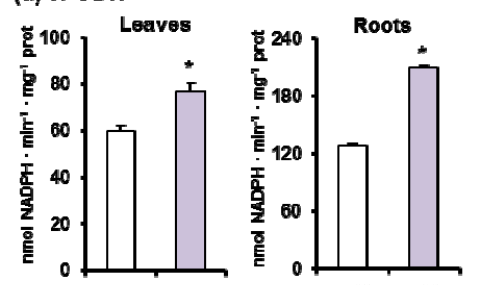

Figure 7. NADP-dehydrogenase activities in leaves and roots of 30-day-old C. maritima plants grown in the presence or absence of $\mathrm{K}^{+}$in the culture medium for 15 days. (a) NADP-isocitrate dehydrogenase (ICDH) activity. (b) NADP-malic enzyme (ME) activity. (c) Glucose-6-phosphate dehydrogenase (G6PDH) activity. (d) 6-phosphogluconate dehydrogenase activity (6PGDH). Data represent the mean \pm SEM of at least three different experiments. Asterisks indicate that differences between values were statistically significant at $p<0.05$.

\section{Discussion}

\section{1. $\mathrm{K}^{+}$Deficiency Alters C. maritima Growth and Induces Oxidative Stress}

$\mathrm{K}^{+}$deficiency disturbs water status in leaves and roots of $C$. maritima, suggesting osmotic stress caused by the lack of this element in the medium. The root is the first organ that senses $\mathrm{K}^{+}$deficiency and consequently, a series of responses occur at physiological, biochemical, and molecular levels. According to [53], at an earlier phase of $\mathrm{K}^{+}$deficiency exposure, cytosolic $\mathrm{K}^{+}$content in plant tissue is regarded as one of the "master switches" which is responsible for plant transition from the ordinary metabolism to a "hibernated state". In C. maritima roots, water stress could be explained by the fact that plant $\mathrm{K}^{+}$ status affects greatly the activity of aquaporins, as revealed by [54] who demonstrated that the activity of aquaporins in tomatoes was suppressed under low $\mathrm{K}^{+}$supply and was associated with a decrease of water transport to shoots. Given its implication in osmotic adjustments, $\mathrm{K}^{+}$deficiency is known to disturb transpiration causing a severe inhibition of leaf expansion [55], supporting our findings on leaves of C. maritima subjected to $\mathrm{K}^{+}$starvation.

$\mathrm{K}^{+}$is implicated in the regulation of guard cells during stomatal movements and its deficiency leads to stomatal closure. Such behavior was documented in sunflowers and olives, in which the $\mathrm{K}^{+}$status greatly affected stomata closure level [56]. This condition leads to an inhibition of photosynthesis rate, transpiration, stomatal conductance, and disturbing plant water relations [57] and, as a consequence, an imbalance between photosynthetic $\mathrm{CO}_{2}$ fixation and excessive accumulation of non-scavenged electrons may provoke the generation of reactive oxygen species (ROS) [58,59]. In Arabidopsis thaliana it was found that the loss of function of the chloroplast $\mathrm{K}^{+}$Efflux Antiporters KEA1 and KEA2, located in the inner envelope membrane, provoked inefficient photosynthesis [60] and altered ROS homeostasis in leaves and roots [61]. It was reported that in plants $\mathrm{K}^{+}$deficiency may act as a stress signal, since $\mathrm{K}^{+}$fluxes in the plants affect the normal functioning of many metabolic processes as well as ROS homeostasis $[3,62,63]$, and may hence induce many adaptive responses to withstand the lack of $\mathrm{K}^{+}$in the medium. $\mathrm{K}^{+}$must trigger cellular signaling alone or in association with other signaling molecules and phytohormones [3,5]. In our case, the estimation of the cellular $\mathrm{K}^{+}$concentration, a crucial parameter for the evaluation of $\mathrm{K}^{+}$status inside the plant cell, demonstrated a significant decrease upon $\mathrm{K}^{+}$deprivation in both leaves and roots. Indeed, cytosolic $\mathrm{K}^{+}$concentration is considered as a signal that affects several metabolic pathways including ROS metabolism. As described by [64], changes in $\mathrm{K}^{+}$status during the first hours of $\mathrm{K}^{+}$starvation resulted in several responses, particularly the ROS metabolism. Furthermore, it has been established that the decrease in cytosolic $\mathrm{K}^{+}$concentration under long-term $\mathrm{K}^{+}$deficiency provoked many morphological and metabolic changes including ROS generation [2]. Taken together, the disruption in plant water relations and the decrease in intracellular $\mathrm{K}^{+}$concentration explain the $\mathrm{K}^{+}$ deficiency-induced oxidative stress in C. maritma. 
It is known that at high levels, superoxide radical $\left(\mathrm{O}_{2}{ }^{\bullet-}\right)$ disrupts the normal functioning of plant cells and, in our experimental conditions, this ROS was accumulated in $\mathrm{K}^{+}$-deficient leaves. A similar increase of $\mathrm{O}_{2}{ }^{\bullet-}$ and $\mathrm{H}_{2} \mathrm{O}_{2}$ contents was found in maize subjected to $\mathrm{K}^{+}$deprivation associated with chloroplast damages [65]. Likewise, $\mathrm{K}^{+}$deficiency increased ROS content in tomato and cotton roots [66,67], soybean, and maize leaves [68]. Like other free radicals, $\mathrm{O}_{2}{ }^{\bullet-}$ may directly or indirectly negatively affect proteins and nucleic acids (DNA and RNA) and cause disruptions to membranes [69,70]. In this context, the analysis of lipid peroxidation showed that in plants grown in $\mathrm{K}^{+}$-deficient medium, MDA content was significantly higher in C. maritima leaves compared to the control. A comparable finding has been described in other plant species $[66,68]$. It has been documented that plant exposure to nutrient deficiency stress is associated with a higher production of free radicals and significant damages to lipid membranes [71], and this depends on the plant species and genotype, as observed in soybean [71] and maize [65].

The increased lipid peroxidation could be due in part to the accumulation of $\mathrm{O}_{2}{ }^{\bullet-}$ and its dismutation to $\mathrm{H}_{2} \mathrm{O}_{2}$, but also to the increased photorespiratory $\mathrm{H}_{2} \mathrm{O}_{2}$ production, resulting from the enhancement of GOX activity in leaf peroxisomes from plants suffering $\mathrm{K}^{+}$deficiency. GOX is very abundant in photosynthetic tissues of $\mathrm{C}_{3}$ plants where it could represent about $1 \%$ of total proteins [72], it has been documented that photorespiration is among the photoprotective mechanisms against oxidative stress when an imbalance in photosynthesis light-harvesting and utilization occurred [73]. Similar findings were obtained by Singh and Blanke (2000) [74], who demonstrated the stimulation of photorespiration under $\mathrm{K}^{+}$shortage conditions. Anthocyanins provide a purple/red appearance of leaves, and they have a photoprotective function $[75,76]$. Our experimental conditions of $\mathrm{K}^{+}$ deficiency triggered a rise of $53 \%$ on the anthocyanin content, which is in good agreement with the general increase of antioxidant systems.

\subsection{Oxidative Stress Is Overcome by a General Induction of the Enzymatic Antioxidant System}

Plants respond to ROS excess through the coordination of complex antioxidant systems including both non-enzymatic (ascorbic acid and glutathione, among others) and enzymatic antioxidants located in different cellular compartments, mainly catalase, SOD, and the ascorbate-glutathione cycle. The role of those antioxidants is to keep ROS homeostasis locally in the cytosol, chloroplasts, peroxisomes, and mitochondria, but also globally within the cell [77-79].

Given the high antioxidant capacity developed by the halophyte C. maritima under various abiotic stresses $[17,28,36]$, we hypothesized a stimulation of its antioxidant systems under $\mathrm{K}^{+}$shortage. The induction of up to seven $\mathrm{CuZn-SOD}$ isozymes in leaves under $\mathrm{K}^{+}$deficiency conditions was outstanding. Our results are also in good agreement with those from Liu et al. (2013) [80] and Li et al. (2020) [11] who demonstrated an increase in total SOD activity in rice and alligator weed plants subjected to $\mathrm{K}^{+}$deficiency for 12 and 15 days, respectively. The inducible CuZn-SODs found in this work were reported to play a primordial role in C. maritima tolerance to various abiotic stress including salinity [28] and mechanical wounding [17]. In those studies, we demonstrated that C. maritima contains a total of ten SOD isozymes: two Mn-SODs, one Fe-SOD, and seven CuZn-SODs, and that $\mathrm{CuZn-SODs}$ were the main isozymes modulated under severe long-term salinity stress. Thus, it is not surprising that these later isozymes might be induced by other abiotic stresses like $\mathrm{K}^{+}$deficiency. A new $\mathrm{CuZn}-\mathrm{SOD}$ isozyme was induced by $\mathrm{Mg}^{2+}$ deficiency in cotton plants [81], thus suggesting that the change of the intensity of existing SOD isozymes or the induction of new ones are among the most adaptive traits to $\mathrm{Mg}^{2+}$ deficiency-induced oxidative stress in Gossypium hirsutum. Likewise, in tomato roots under salinity stress and treated with a nitric oxide donor, it was found that there was an induction of the CuZn-SOD (III) in roots, suggesting that nitric oxide could exert a regulation at the protein and gene level of this antioxidant enzyme [82], being a plausible issue in C. maritima that deserves to be explored. 
$\mathrm{H}_{2} \mathrm{O}_{2}$ generated by the enhanced activity of SOD under $\mathrm{K}^{+}$starvation may also stimulate other antioxidant components in C. maritima under such conditions. In this regard, $\mathrm{H}_{2} \mathrm{O}_{2}$ is recognized as a key signaling molecule [83] and, under $\mathrm{K}^{+}$deficiency, a general increase of the most relevant antioxidant systems that control $\mathrm{H}_{2} \mathrm{O}_{2}$ cellular content such as catalase, located in peroxisomes [84], and all the enzymes of the ascorbate-glutathione cycle in leaves and roots of $C$. maritima plants was observed. These findings support previous reports indicating that the lack of $\mathrm{K}^{+}$in the medium affects ROS metabolism in different plant species. It has been pointed out that short (one-seven days) or long-term (14-60 days) $\mathrm{K}^{+}$ starvation differently affected the antioxidant response in plants $[6,66,68]$. According to the literature, under low $\mathrm{K}^{+}$supply catalase activity was enhanced, unaffected, or diminished and was modulated depending on the plant organ. In rice [85] and Brassica juncea [86], $\mathrm{K}^{+}$ deprivation led to an increase in catalase activity, whereas a decrease of this activity was observed in Solanum lycopersicum roots [66].

On the other hand, peroxidases (POX) ensure multiple biological processes in plant cells. Our data indicated that an overall increase of POX activity takes place in C. maritima due to $\mathrm{K}^{+}$shortage. Hafsi et al. (2011) [8] also demonstrated an induction of guaiacol peroxidase activity in wheat subjected to $\mathrm{K}^{+}$starvation. The sensitive genotype of potato grown under $\mathrm{K}^{+}$deficiency also showed the highest CAT and POX activities in roots compared to the tolerant one [10]. A modulation of POX activity was observed as well upon $\mathrm{K}^{+}$deficiency, as revealed by transcription analysis in rice [87]. Recently, proteomic studies of the antioxidant enzymes showed changes in abundance of SOD, POX, glutathione-S-transferase (GST), and glutathione peroxidase (GPX) in stems of alligator weed (Alternanthera philoxeroides) plants under $\mathrm{K}^{+}$-deficiency stress [88]. More recently, quantitative proteomic analysis of alligator weed leaves demonstrated an increase in abundance of cationic peroxidase 1 (ApCPX1) which played a relevant role when plants underwent $\mathrm{K}^{+}$deficiency stress [11].

Specific ascorbate peroxidase (APX) isozyme activities, analyzed by spectrophotometric assay and native PAGE, were increased in leaves and roots from $\mathrm{K}^{+}$-deficient $\mathrm{C}$. maritima plants. Liu et al. (2013) [80] and Ahmad et al. (2014) [86] reported an enhancement of APX activity in rice and $B$. juncea under limiting $\mathrm{K}^{+}$supply. Such results provide evidence for the important role of APX in $\mathrm{H}_{2} \mathrm{O}_{2}$ detoxification in the different organelles under unfavorable conditions $[89,90]$. At the molecular level, several studies have revealed an upregulation of genes encoding peroxidases in A. thaliana [91] and S. lycopersicum [66]. APX and other peroxidases are good ROS scavengers that may also operate at the apoplast together with $\mathrm{CuZn-SODs,} \mathrm{thus} \mathrm{contributing} \mathrm{to} \mathrm{mitigate} \mathrm{the} \mathrm{harmful} \mathrm{effects} \mathrm{of} \mathrm{oxidative} \mathrm{stress.}$

Several enzymes of the ascorbate-glutathione cycle are implicated in $\mathrm{H}_{2} \mathrm{O}_{2}$ detoxification: APX, MDAR, DHAR, and GR. A stimulation of GR, MDAR, and DHAR activities was noted under $\mathrm{K}^{+}$deficiency in C. maritima. Hafsi et al. (2011) [8] found an increase of DHAR and MDAR activities in Hordeum maritimum exposed to $\mathrm{K}^{+}$deprivation and attributed such results to the fact that both enzymes generate ascorbate implicated in $\mathrm{H}_{2} \mathrm{O}_{2}$ detoxification. $\mathrm{K}^{+}$deficiency also enhanced the activity of GR in rice leaves [80] and cotton roots [67]. This enzyme reduces oxidized glutathione (GSSG) to GSH, a tripeptide that is involved in antioxidant processes under stressful conditions [92].

ROS metabolism plays a key role in the acclimation process of plants to abiotic stress. $\mathrm{H}_{2} \mathrm{O}_{2}$ produced through the activity of GOX, SOD, and perhaps other enzymes can be used as a signaling molecule that plays an important role in C. maritima acclimation to $\mathrm{K}^{+}$deficiency. Many studies highlight the ability of plants to use ROS in many signaling pathways [93-96]. ROS is involved in the signaling cascade that induces the expression of genes coding for HAK5, a high-affinity $\mathrm{K}^{+}$transporter [97]. Furthermore, it has been reported that, under $\mathrm{K}^{+}$deficiency conditions, the interplay between ROS accumulation and increased ethylene production is a key in signaling $\mathrm{K}^{+}$root status and activating many morphological adaptations to $\mathrm{K}^{+}$deficiency, such as primary root growth, root hair elongation, and induction of HAK5, resulting in an enhancement of $\mathrm{K}^{+}$uptake and plant survival under $\mathrm{K}^{+}$limiting conditions [98,99]. Moreover, overexpression of peroxidase in 
Arabidopsis thaliana has been discussed to improve AtHAK5 expression in response to $\mathrm{K}^{+}$ shortage conditions through its contribution to ROS production [100].

\section{3. $\mathrm{K}^{+}$Deficiency Triggers a General Increase of the NADPH-Generating Systems}

For a deeper knowledge about the likely role of NADPH as a second line of defense to support some of the antioxidant systems [17] in C. maritima under $\mathrm{K}^{+}$shortage and given the lack of information on NADPH implication in plant response to $\mathrm{K}^{+}$deficiency in other species, we assessed the activity of four main enzymes responsible for its generation. Our results show that the activity of NADP-ICDH, NADP-ME, G6PDH, and 6PGDH increased by low $\mathrm{K}^{+}$availability in leaves and roots. The stimulation of NADPH-generating enzymes has been described under various abiotic stresses including salinity, heavy metal stress, and drought $[16,18,21,51,101-106]$. For example, under chromium stress, all NADPDHs were increased in roots and coleoptile of maize seedlings [15] and in A. thaliana, $20 \mu \mathrm{M}$ glyphosate stimulated the activity of G6PDH and 6PGDH [20]. More recently, Houmani et al. (2018) [17] demonstrated an increase of NADP-ICDH under mechanical wounding in seven-day-old C. maritima seedlings. Using quantitative proteomic analyses, Li et al. (2018) [107] demonstrated downregulation of NADP-ICDH abundance upon $\mathrm{K}^{+}$ deprivation in roots of Alternanthera philoxeroides and they explained such results by the fact that this enzyme is responsible for citric acid accumulation which in turn is secreted into the soil solution to dissolve $\mathrm{K}^{+}$and facilitate its absorption at the root plasma membrane. Globally, all these data support the relevance of the NADPH-generating systems under adverse environmental conditions and specifically in the $\mathrm{K}^{+}$nutrition in plants.

\section{Conclusions}

All the obtained biochemical results indicate that under low $\mathrm{K}^{+}$availability, C. maritima plants undergo oxidative stress. This event triggers a general boost of the antioxidant systems, particularly the induction of up to seven new CuZn-SOD isozymes. Likewise, $\mathrm{K}^{+}$ starvation induces a generalized increase in the enzymes responsible for generating reducing power in the form of NADPH, which contributes to maintaining the cellular redox homeostasis. All these biochemical mechanisms allow C. maritima to survive under $\mathrm{K}^{+}$ starvation, conditions that do not allow the survival of other plant species (Figure 8). Considering that some terrestrial areas undergo a growing deterioration in the quality of the land due to a lack of nutrients such as $\mathrm{K}^{+}$, or the increasing soil salinization where glycophytic plants cannot survive, C. maritima should be considered an alternative crop for this type of soil. Furthermore, C. maritima is a halophyte plant that has been used for different purposes, such as culinary uses and as a dried ingredient in flours to make bread or flavoring for salads; and its seeds are also appreciated for its oils which constitute around $40 \%$ of its dry weight [32,33]. Likewise, another industrial potential use could be for its high content of antioxidant enzymes such as the CuZn-SOD, which is induced under $\mathrm{K}^{+}$availability (the present study) or high salinity [28]. These potentialities could be explored due to further applications, either as a nutraceutical complement or for therapeutic/industrial use since antioxidant enzymes are emerging components for the pool of industrial enzymes. 


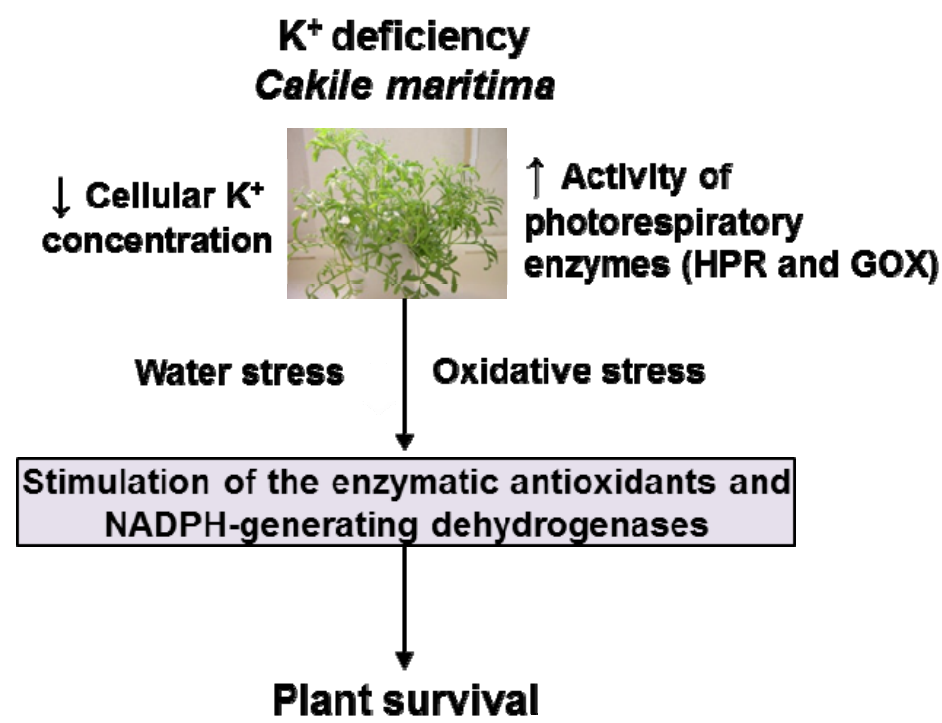

Figure 8. Model of the mechanism of response of halophyte $C$. maritima grown under $\mathrm{K}^{+}$deficiency. GOX, glycolate oxidase. HPR, hydroxypyruvate reductase.

Author Contributions: H.H. and F.J.C. conceived and designed the experiments. H.H. carried out experiments and collected, analyzed, and interpreted the data. L.d.F.-S. analyzed and interpreted the data. H.H., F.J.C., A.D., C.A. interpreted the data and wrote the first draft preparation. F.J.C. and J.M.P. critically revised and edited the article. All authors have read and agreed to the published version of the manuscript.

Funding: F.J.C. and J.M.P. research is supported by ERDF-cofinanced grant from the Ministry of Science and Innovation (BIO2012-33904), Ministry of Economy and Competitiveness (PID2019103924GB-I00), the Plan Andaluz de Investigación, Desarrollo e Innovación (PAIDI 2020) (P18-FR1359), and Junta de Andalucía (group BIO192).

Institutional Review Board Statement: Not applicable.

Informed Consent Statement: Not applicable.

Data Availability Statement: Data is contained within the article.

Acknowledgments: H.H. acknowledges a short-term scholarship from Tunisian Government and thanks their collaborators from the Laboratory of Extremophile Plants. The valuable technical help of Carmelo Ruiz-Torres is deeply appreciated.

Conflicts of Interest: The authors declare no conflict of interest.

\section{References}

1. Ragel, P.T.; Raddatz, N.T.; Leidi, E.O.T.; Quintero, F.J.T.; Pardo, J.M. Regulation of $\mathrm{K}^{+}$nutrition in plants. Front. Plant Sci. 2019, 10, 281. [CrossRef] [PubMed]

2. Wang, Y.; Wu, W.H. Potassium transport and signaling in higher plants. Annu. Rev. Plant Biol. 2013, 64, 451-476. [CrossRef] [PubMed]

3. Hasanuzzaman, M.; Bhuyan, M.; Nahar, K.; Hossain, M.; Mahmud, J.; Hossen, M.; Masud, A.; Fujita, M. Potassium: A vital regulator of plant responses and tolerance to abiotic stresses. Agronomy 2018, 8, 31. [CrossRef]

4. Tighe-Neira, R.; Alberdi, M.; Arce-Johnson, P.; Romero, J.; Reyes-Díaz, M.; Rengel, Z.; Inostroza-Blancheteau, C. Role of potassium in governing photosynthetic processes and plant yield. In Plant Nutrients and Abiotic Stress Tolerance; Hasanuzzaman, M., Fujita, M., Oku, H., Nahar, K., Hawrylak-Nowak, B., Eds.; Springer: Singapore, 2018; pp. 191-203. [CrossRef]

5. Lana, L.G.; de Araújo, L.M.; Silva, T.F.; Modolo, L.V. Interplay between gasotransmitters and potassium is a Key factor during plant response to abiotic stress. Plant Phys. Biochem. 2021, 169, 322-332. [CrossRef]

6. Hafsi, C.; Debez, A.; Abdelly, C. Potassium deficiency in plants: Effects and signaling cascades. Acta Physiol. Plant. 2014, 36, 1055-1070. [CrossRef]

7. Yadav, B.K.; Sidhu, A.S. Dynamics of potassium and their bioavailability for plant nutrition. In Potassium Solubilizing Microorganisms for Sustainable Agriculture; Meena, V., Maurya, B., Verma, J., Meena, R., Eds.; Springer: New Delhi, India, 2016 ; pp. 187-201. [CrossRef] 
8. Hafsi, C.; Romero-Puertas, M.C.; del Río, L.A.; Abdelly, C.; Sandalio, L.M. Antioxidative response of Hordeum martitimum L. to potassium deficiency. Acta Physiol. Plant. 2011, 33, 193-202. [CrossRef]

9. Hafsi, C.; Falleh, H.; Saada, M.; Ksouri, R.; Abdelly, C. Potassium deficiency alters growth, photosynthetic performance, secondary metabolites content, and related antioxidant capacity in Sulla carnosa grown under moderate salinity. Plant Physiol. Biochem. 2017, 118, 609-617. [CrossRef]

10. Liu, M.; Zhang, A.-J.; Chen, X.G.; Jin, R.; Li, H.M.; Tang, Z.H. Effects of potassium deficiency on root morphology, ultrastructure and antioxidant enzyme system in sweet potato (Ipomoea batatas [L.] Lam.) during early growth. Acta Physiol. Plant. 2017, 39, 211. [CrossRef]

11. Li, L.Q.; Lyu, C.C.; Li, J.H.; Wan, C.Y.; Liu, L.; Xie, M.Q.; Zuo, R.J.; Ni, S.; Liu, F.; Zeng, F.C.; et al. Quantitative proteomic analysis of alligator weed leaves reveals that cationic peroxidase 1 plays vital roles in the potassium deficiency stress response. Int. J. Mol. Sci. 2020, 21, 2537. [CrossRef]

12. Houmani, H.; Debez, A.; Slatni, T.; Yousfi, S.; Jellali, N.; M'sehli, W.; Abdelly, C.; Gharsalli, M. Insights into physiological responses of the halophyte Suaeda fruticosa to simultaneous salinity and iron deficiency. CLEAN-Soil Air Water 2015, 43, 382-390. [CrossRef]

13. Kohli, S.K.; Khanna, K.; Bhardwaj, R.; Abd Allah, E.F.; Ahmad, P.; Corpas, F.J. Assessment of Subcellular ROS and NO Metabolism in Higher Plants: Multifunctional Signaling Molecules. Antioxidants 2019, 8, 641. [CrossRef]

14. Santini, R.; de Lima, J.P.; Gratão, P.L.; Camargo, A.F.M. Evaluation of growth and oxidative stress as indicative of salinity tolerance by the invasive tropical aquatic macrophyte tanner grass. Hydrobiologia 2022, 1-11. [CrossRef]

15. Kharbech, O.; Houmani, H.; Chaoui, A.; Corpas, F.J. Alleviation of Cr(VI)-induced oxidative stress in maize (Zea mays L.) seedlings by $\mathrm{NO}$ and $\mathrm{H} 2 \mathrm{~S}$ donors through differential organ-dependent regulation of ROS and NADPH-recycling metabolisms. J. Plant Physiol. 2017, 219, 71-80. [CrossRef]

16. Rodríguez-Ruiz, M.; Aparicio-Chacón, M.V.; Palma, J.M.; Corpas, F.J. Arsenate disrupts ion balance, sulfur and nitric oxide metabolisms in roots and leaves of pea (Pisum sativum L.) plants. Environ. Exp. Bot. 2019, 161, 143-156. [CrossRef]

17. Houmani, H.; Rodríguez-Ruiz, M.; Palma, J.M.; Corpas, F.J. Mechanical wounding promotes local and long distance response in the halophyte Cakile maritima through the involvement of the ROS and RNS metabolism. Nitric Oxide. 2018, 74, 93-101. [CrossRef]

18. Corpas, F.J.; Barroso, J.B. Functional implications of peroxisomal nitric oxide (NO) in plants. Front. Plant Sci. 2014, 5, 97. [CrossRef]

19. Corpas, F.J.; Aguayo-Trinidad, S.; Ogawa, T.; Yoshimura, K.; Shigeoka, S. Activation of NADPH-recycling systems in leaves and roots of Arabidopsis thaliana under arsenic-induced stress conditions is accelerated by knock-out of Nudix hydrolase 19 (AtNUDX19) gene. J. Plant Physiol. 2016, 192, 81-89. [CrossRef]

20. de Freitas-Silva, L.; Rodríguez-Ruiz, M.; Houmani, H.; da Silva, L.C.; Palma, J.M.; Corpas, F.J. Glyphosate-induced oxidative stress in Arabidopsis thaliana affecting peroxisomal metabolism and triggers activity in the oxidative phase of the pentose phosphate pathway (OxPPP) involved in NADPH generation. J. Plant Physiol. 2017, 218, 196-205. [CrossRef]

21. Ruíz-Torres, C.; Feriche-Linares, R.; Rodríguez-Ruíz, M.; Palma, J.M.; Corpas, F.J. Arsenic-induced stress activates sulfur metabolism in different organs of garlic (Allium sativum L.) plants accompanied by a general decline of the NADPH-generating systems in roots. J. Plant Physiol. 2017, 211, 27-35. [CrossRef]

22. Aghdam, M.S.; Palma, J.M.; Corpas, F.J. NADPH as a quality footprinting in horticultural crops marketability. Trends Food Sci. Technol. 2020, 103, 152-161. [CrossRef]

23. Cardi, M.; Castiglia, D.; Ferrara, M.; Guerriero, G.; Chiurazzi, M.; Esposito, S. The effects of salt stress cause a diversion of basal metabolism in barley roots: Possible different roles for glucose-6-phosphate dehydrogenase isoforms. Plant Physiol. Biochem. 2015, 86, 44-54. [CrossRef] [PubMed]

24. Esposito, S. Nitrogen Assimilation, abiotic stress and glucose 6-phosphate dehydrogenase: The full circle of reductants. Plants 2016, 5, 24. [CrossRef] [PubMed]

25. Rani, M.; Mahato, A.K.; Sinha, S.K.; Dalal, M.; Singh, N.K.; Mandal, P.K. Homeologue specific gene expression analysis of two vital carbon metabolizing enzymes-Citrate synthase and NADP-isocitrate dehydrogenase-From wheat (Triticum aestivum L.) under nitrogen stress. Appl. Biochem. Biotechnol. 2019, 188, 569-584. [CrossRef]

26. Corpas, F.J.; González-Gordo, S.; Palma, J.M. Nitric oxide and hydrogen sulfide modulate the NADPH-generating enzymatic system in higher plants. J. Exp. Bot. 2021, 72, 830-847. [CrossRef]

27. Li, Z.; Jiang, H.; Yan, H.; Jiang, X.; Ma, Y.; Qin, Y. Carbon and nitrogen metabolism under nitrogen variation affects flavonoid accumulation in the leaves of Coreopsis tinctoria. Peer] 2021, 9, e12152. [CrossRef] [PubMed]

28. Houmani, H.; Rodríguez-Ruiz, M.; Palma, J.M.; Abdelly, C.; Corpas, F.J. Modulation of superoxide dismutase (SOD) isozymes by organ development and high long-term salinity in the halophyte Cakile maritima. Protoplasma 2016, 3, 885-894. [CrossRef] [PubMed]

29. Debez, A.; Belghith, I.; Pich, A.; Taamalli, W.; Abdelly, C.; Braun, H.P. High salinity impacts germination of the halophyte Cakile maritima but primes seeds for rapid germination upon stress release. Physiol. Plant. 2018, 164, 134-144. [CrossRef]

30. Arbelet-Bonnin, D.; Ben-Hamed-Louati, I.; Laurenti, P.; Abdelly, C.; Ben-Hamed, K.; Bouteau, F. Cakile maritima, a promising model for halophyte studies and a putative cash crop for saline agriculture. Adv. Agron. 2019, 155, 45-78. [CrossRef]

31. Farhat, N.; Belghith, I.; Senkler, J.; Hichri, S.; Abdelly, C.; Braun, H.P.; Debez, A. Recovery aptitude of the halophyte Cakile maritima upon water deficit stress release is sustained by extensive modulation of the leaf proteome. Ecotoxicol. Environ. Saf. 2019, 179, 198-211. [CrossRef] 
32. Agudelo, A.; Carvajal, M.; Martinez-Ballesta, M.D.C. Halophytes of the Mediterranean basin-underutilized species with the potential to be nutritious crops in the scenario of the climate change. Foods 2021, 10, 119. [CrossRef]

33. Zitouni, M.; Wewer, V.; Dörmann, P.; Abdelly, C.; Ben Youssef, N. Quadrupole time-of-flight mass spectrometry analysis of glycerophospholipid molecular species in the two halophyte seed oils: Eryngium maritimum and Cakile maritima. Food Chem. 2016, 213, 319-328. [CrossRef] [PubMed]

34. Debez, A.; Rejeb, K.B.; Ghars, M.A.; Gandour, M.; Megdiche, W.; Hamed, K.B.; Ben Amor, N.; Brown, S.C.; Savouré, A.; Abdelly, C. Ecophysiological and genomic analysis of salt tolerance of Cakile maritima. Environ. Exp. Bot. 2013, 92, 64-72. [CrossRef]

35. Debez, A.; Koyro, H.W.; Grignon, C.; Abdelly, C.; Huchzermeyer, B. Relationship between the photosynthetic activity and the performance of Cakile maritima after long-term salt treatment. Physiol. Plant. 2008, 133, 373-385. [CrossRef] [PubMed]

36. Ellouzi, H.; Ben Hamed, K.; Cela, J.; Munné-Bosch, S.; Abdelly, C. Early effects of salt stress on the physiological and oxidative status of Cakile maritima (halophyte) and Arabidopsis thaliana (glycophyte). Physiol. Plant. 2011, 142, 128-143. [CrossRef] [PubMed]

37. Waqas, M.; Yaning, C.; Iqbal, H.; Shareef, M.; Rehman, H.U.; Bilal, H.M. Synergistic consequences of salinity and potassium deficiency in quinoa: Linking with stomatal patterning, ionic relations and oxidative metabolism. Plant Physiol. Biochem. 2021, 159, 17-27. [CrossRef] [PubMed]

38. Buege, J.A.; Aust, S.D. Microsomal lipid peroxidation. Meth. Enzymol. 1978, 52, 302-310. [CrossRef]

39. Vargas, W.A.; Martín, J.M.; Rech, G.E.; Rivera, L.P.; Benito, E.P.; Díaz-Mínguez, J.M.; Thon, M.R.; Sukno, S.A. Plant defense mechanisms are activated during biotrophic and necrotrophic development of Colletotricum graminicola in maize. Plant Physiol. 2012, 158, 1342-1358. [CrossRef]

40. Gould, K.S.; Markham, K.R.; Smith, R.H.; Goris, J.J. Functional role of anthocyanins in the leaves of Quintinia serrata A. Cunn. J. Exp. Bot. 2000, 51, 1107-1115. [CrossRef]

41. Beauchamp, C.O.; Fridovich, I. Superoxide dismutase: Improved assays and an assay applicable to acrylamide gels. Anal. Biochem. 1971, 44, 276-287. [CrossRef]

42. Ádám, A.L.; Bestwick, C.S.; Barna, B.; Mansfield, J.W. Enzymes regulating the accumulation of active oxygen species during the hypersensitive reaction of bean to Pseudomonas syringae pv. Phaseolicola. Planta 1995, 7, 240-249. [CrossRef]

43. Bieker, S.; Riester, L.; Stahl, M.; Franzaring, J.; Zentgraf, U. Senescence specific-Alteration of hydrogen peroxide levels in Arabidopsis thaliana and oilseed rape spring variety Brassica napus L. cv. Mozart F. J. Integr. Plant Biol. 2012, 54, 540-554. [CrossRef] [PubMed]

44. Kerr, M.W.; Groves, D. Purification and properties of glycollate oxidase from Pisum sativum leaves. Phytochemistry 1975, 14, 359-362. [CrossRef]

45. Aebi, H. Catalase in vitro. Meth. Enzymol. 1984, 105, 121-126. [CrossRef]

46. Hossain, M.A.; Asada, K. Inactivation of ascorbate peroxidase in spinach chloroplasts on dark addition of hydrogen peroxide: Its protection by ascorbate. Plant Cell Physiol. 1984, 25, 1285-1295. [CrossRef]

47. Hossain, M.A.; Nakano, Y.; Asada, K. Monodehydroascorbate reductase in spinach chloroplasts and its participation in regeneration of ascorbate for scavenging hydrogen peroxide. Plant Cell Physiol. 1984, 25, 385-395. [CrossRef]

48. Edwards, E.A.; Rawsthone, S.; Mullineaux, P.M. Subcellular distribution of multiple forms of glutathione reductase in leaves of pea (Pisum sativum L.). Planta 1990, 180, 278-284. [CrossRef]

49. Dalton, D.A.; Baird, L.M.; Langeberg, L.; Taugher, C.Y.; Anyan, W.R.; Vance, C.V.; Sarath, G. Subcellular localization of oxygen defense enzymes in soybean (Glycine max L. Merr) root nodules. Plant Physiol. 1993, 102, 481-489. [CrossRef]

50. Barroso, J.B.; Peragón, J.; Contreras-Jurado, C.; García-Salguero, L.; Corpas, F.J.; Esteban, F.J.; Peinado, M.A.; De La Higuera, M.; Lupiáñez, J.A. Impact of starvation-refeeding on kinetics and protein expression of trout liver NADPH-production systems. Am. J. Physiol. 1998, 274, 1578-1587. [CrossRef]

51. Leterrier, M.; Barroso, J.B.; Valderrama, R.; Palma, J.M.; Corpas, F.J. NADP-dependent isocitrate dehydrogenase from Arabidopsis roots contributes in the mechanism of defence against the nitro-oxidative stress induced by salinity. Sci. World J. 2012, 2012, 694740. [CrossRef]

52. Mateos, R.M.; Bonilla-Valverde, D.; del Río, L.A.; Palma, J.M.; Corpas, F.J. NADP-dehydrogenases from pepper fruits: Effect of maturation. Physiol. Plant. 2009, 135, 130-139. [CrossRef]

53. Shabala, S.; Pottosin, I. Regulation of potassium transport in plants under hostile conditions: Implications for abiotic and biotic stress tolerance. Physiol Plant. 2014, 151, 257-279. [CrossRef]

54. Kanai, S.; Moghaieb, R.E.; El-Shemy, H.A.; Panigrahi, R.; Mohapatra, P.K.; Ito, J.; Nguyen, N.T.; Saneoka, H.; Fujita, K. Potassium deficiency affects water status and photosynthetic rate of the vegetative sink in green house tomato prior to its effects on source activity. Plant Sci. 2011, 180, 368-374. [CrossRef]

55. Tavakol, E.; Jákli, B.; Cakmak, I.; Dittert, K.; Karlovsky, P.; Pfohl, K.; Senbayram, M. Optimized potassium nutrition improves plant-water-relations of barley under PEG-induced osmotic stress. Plant Soil 2018, 430, 23-35. [CrossRef]

56. Benlloch-González, M.; Arquero, O.; Fournier, J.M.; Barranco, D.; Benlloch, M. $\mathrm{K}^{+}$starvation inhibits water-stress-induced stomatal closure. J. Plant Physiol. 2008, 165, 623-630. [CrossRef]

57. Jin, S.H.; Huang, J.Q.; Li, X.Q.; Zheng, B.S.; Wu, J.S.; Wang, Z.J.; Liu, G.H.; Chen, M. Effects of potassium supply on limitations of photosynthesis by mesophyll diffusion conductance in Carya cathayensis. Tree Physiol. 2011, 31, 1142-1151. [CrossRef]

58. Ashraf, M.; Akram, N.A. Improving salinity tolerance of plants through conventional breeding and genetic engineering: An analytical comparison. Biotechnol. Adv. 2009, 27, 74452. [CrossRef] 
59. Suzuki, N.; Koussevitzky, S.; Mittler, R.; Miller, G. ROS and redox signalling in the response of plants to abiotic stress. Plant Cell Environ. 2012, 35, 259-270. [CrossRef]

60. Aranda-Sicilia, M.N.; Aboukila, A.; Armbruster, U.; Cagnac, O.; Schumann, T.; Kunz, H.H.; Jahns, P.; Rodríguez-Rosales, M.P.; Sze, H.; Venema, K. Envelope $\mathrm{K}^{+} / \mathrm{H}^{+}$ntiporters AtKEA1 and AtKEA2 function in plastid development. Plant Physiol. 2016, 172, 441-449. [CrossRef]

61. Sánchez-McSweeney, A.; González-Gordo, S.; Aranda-Sicilia, M.N.; Rodríguez-Rosales, M.P.; Venema, K.; Palma, J.M.; Corpas, F.J. Loss of function of the chloroplast membrane $\mathrm{K}^{+} / \mathrm{H}^{+}$antiporters AtKEA1 and AtKEA2 alters the ROS and NO metabolism but promotes drought stress resilience. Plant Physiol. Biochem. 2021, 160, 106-119. [CrossRef]

62. Ma, T.L.; Wu, W.H.; Wang, Y. Transcriptome analysis of rice root responses to potassium deficiency. BMC Plant Biol. 2012, $12,161$. [CrossRef]

63. Mahiwal, S.; Pandey, G.K. Potassium: An emerging signal mediator in plants? In Plant Nutrition and Food Security in the Era of Climate Change; Academic Press: Cambridge, MA, USA, 2022; pp. 97-118. [CrossRef]

64. Wang, Y.; Wu, W.H. Plant sensing and signaling in response to $\mathrm{K}^{+}$-deficiency. Mol. Plant 2010, 3, 280-287. [CrossRef] [PubMed]

65. Qi, D.U.; Zhao, X.H.; Le, X.I.A.; Jiang, C.J.; Wang, X.G.; Yi, H.A.N.; Jing, W.A.N.G.; Yu, H.Q. Effects of potassium deficiency on photosynthesis, chloroplast ultrastructure, ROS, and antioxidant activities in maize (Zea mays L.). J. Integr. Agric. 2019, 18, 395-406. [CrossRef]

66. Hernández, M.; Fernández-García, N.; García-Garma, J.; Rubio-Asensio, J.S.; Rubio, F.; Olmos, E. Potassium starvation induces oxidative stress in Solanum lycopersicum L. roots. J. Plant Physiol. 2012, 169, 1366-1374. [CrossRef]

67. Zhang, Z.; Zhang, X.; Hu, Z.; Wang, S.; Zhang, J.; Wang, X.; Wang, Q.; Zhang, B. Lack of K-dependent oxidative stress in cotton roots following coronatine-induced ROS accumulation. PLoS ONE 2015, 10, e0126476. [CrossRef]

68. Gong, X.; Chao, L.; Zhou, M.; Hong, M.; Luo, L.; Wang, L.; Ying, W.; Jingwei, C.; Songjie, G.; Fashui, H. Oxidative damages of maize seedlings caused by exposure to a combination of potassium deficiency and salt stress. Plant Soil 2011, 340, 443-452. [CrossRef]

69. Perveen, S.; Shahbaz, M.; Ashraf, M. Is pre-sowing seed treatment with triacontanol effective in improving some physiological and biochemical attributes of wheat (Triticum aestivum L.) under salt stress? J. Appl. Bot. Food Qual. 2012, 85, 418.

70. Akram, N.A.; Ashraf, M.; Al-Qurainy, F. Aminolevulinic acid-induced regulation in some key physiological attributes and activities of antioxidant enzymes in sunflower (Helianthus annuus L.) under saline regimes. Sci. Hort. 2012, 142, 1438. [CrossRef]

71. Miao, B.H.; Han, X.G.; Zhang, W.H. The ameliorative effect of silicon on soybean seedlings grown in potassium-deficient medium Ann. Bot. 2010, 105, 967-973. [CrossRef]

72. Ferreira, R.M.B. The Metabolic Responses of Plants to Stress, with Particular Reference to Protein Turnover. Ph.D. Thesis, University of East Anglia, Norwich, UK, 1987.

73. Malnoë, A. Photoinhibition or photoprotection of photosynthesis? Update on the (newly termed) sustained quenching component qH. Environ. Exp. Bot. 2018, 154, 123-133. [CrossRef]

74. Singh, P.; Blanke, M. Deficiency of potassium but not phosphorus enhances root respiration. Plant Growth Regul. 2000, 32, 77-81. [CrossRef]

75. Gould, K.S.; McKelvie, J.; Markham, K.R. Do anthocyanins function as antioxidants in leaves? Imaging of $\mathrm{H}_{2} \mathrm{O}_{2}$ in red and green leaves after mechanical injury. Plant Cell Environ. 2002, 25, 1261-1269. [CrossRef]

76. Li, Y.C.; Lin, T.C.; Martin, C.E. Leaf anthocyanin, photosynthetic light-use efficiency, and ecophysiology of the South African succulent Anacampseros rufescens (Anacampserotaceae). S. Afr. J. Bot. 2015, 99, 122-128. [CrossRef]

77. Corpas, F.J. What is the role of hydrogen peroxide in plant peroxisomes? Plant Biol. 2015, 17, 1099-1103. [CrossRef] [PubMed]

78. del Río, L.A.; Corpas, F.J.; López-Huertas, E.; Palma, J.M. Plant superoxide dismutases: Function under abiotic stress conditions. In Antioxidants and Antioxidant Enzymes in Higher Plants; Gupta, D.K., Palma, J.M., Corpas, F.J., Eds.; Springer International Publishing: Cham, Switzerland, 2018; pp. 1-26.

79. Palma, J.M.; Corpas, F.J. Editorial: Subcellular Compartmentalization of plant antioxidants and ROS generating systems. Front. Plant Sci. 2021, 12, 643239. [CrossRef]

80. Liu, C.H.; Chao, Y.Y.; Kao, C.H. Effect of potassium deficiency on antioxidant status and cadmium toxicity in rice seedlings. Bot. Stud. 2013, 54, 2. [CrossRef]

81. Özgüruzilda, R.; Uzilday, B.; Yalçinkaya, T.; Türkan, I. Mg deficiency changes the isoenzyme pattern of reactive oxygen speciesrelated enzymes and regulates NADPH oxidase-mediated ROS signaling in cotton. Turk. J. Biol. 2017, 41, 868-880. [CrossRef]

82. Manai, J.; Kalai, T.; Gouia, H.; Corpas, F.J. Exogenous nitric oxide (NO) ameliorates salinity-induced oxidative stress in tomato (Solanum lycopersicum) plants. J. Soil Sci. Plant Nutr. 2014, 14, 433-446. [CrossRef]

83. Foyer, C.H.; Ruban, A.V.; Nixon, P.J. Photosynthesis solutions to enhance productivity. Philos. Trans. R. Soc. B Biol. Sci. 2017, 372, 3-6. [CrossRef]

84. Palma, J.M.; Mateos, R.M.; López-Jaramillo, J.; Rodríguez-Ruiz, M.; González-Gordo, S.; Lechuga-Sancho, A.M.; Corpas, F.J. Plant catalases as $\mathrm{NO}$ and $\mathrm{H}_{2} \mathrm{~S}$ targets. Redox Biol. 2020, 34, 101525. [CrossRef]

85. Ding, Y.C.; Chang, C.R.; Luo, W.; Wu, Y.S.; Ren, X.L.; Wang, P.; Xu, G.H. High potassium aggravates the oxidative stress induced by magnesium deficiency in rice leaves. Pedosphere 2008, 18, 316-327. [CrossRef]

86. Ahmad, I.; Maathuis, F.J. Cellular and tissue distribution of potassium: Physiological relevance, mechanisms and regulation. J. Plant Physiol. 2014, 171, 708-714. [CrossRef] [PubMed] 
87. Shankar, A.; Singh, A.; Kanwar, P.; Srivastava, A.K.; Pandey, A.; Suprasanna, P.; Kapoor, S.; Pandey, G.K. Gene expression analysis of rice seedling under potassium deprivation reveals major changes in metabolism and signalling components. PLoS ONE 2013, 8, e70321. [CrossRef] [PubMed]

88. Li, L.; Lyu, C.; Huang, L.; Chen, Q.; Zhuo, W.; Wang, X.; Lu, Y.; Zeng, F.; Lu, L. Physiology and proteomic analysis reveals root, stem and leaf responses to potassium deficiency stress in alligator weed. Sci. Rep. 2019, 9, 17366. [CrossRef] [PubMed]

89. Foyer, C.H.; Noctor, G. Ascorbate and glutathione: The heart of the redox hub. Plant Physiol. 2011, 155, 2-18. [CrossRef] [PubMed]

90. Corpas, F.J.; del Río, L.A.; Palma, J.M. Impact of Nitric Oxide (NO) on the ROS Metabolism of Peroxisomes. Plants 2019, 8, 37. [CrossRef] [PubMed]

91. Armengaud, P.; Breitling, R.; Amtmann, A. The potassium-dependent transcriptome of Arabidopsis reveals a prominent role of jasmonic acid in nutrient signaling. Plant Physiol. 2004, 136, 2556-2576. [CrossRef]

92. Gill, S.S.; Tuteja, N. Reactive oxygen species and antioxidant machinery in abiotic stress tolerance in crop plants. Plant Physiol. Biochem. 2010, 48, 909-930. [CrossRef]

93. Foyer, C.H.; Noctor, G. Redox signaling in plants. Antioxid. Redox Signal. 2013, 18, 2087-2090. [CrossRef]

94. Vaahtera, L.; Brosche, M.; Wrzaczek, M.; Kangasjarvi, J. Specificity in ROS signaling and transcript signatures. Antioxid. Redox Signal. 2014, 21, 1422-1441. [CrossRef]

95. Considine, M.J.; Sandalio, L.M.; Foyer, C.H. Unravelling how plants benefit from ROS and NO reactions, while resisting oxidative stress. Ann. Bot. 2015, 116, 469-473. [CrossRef]

96. Mignolet-Spruyt, L.; Xu, E.; Idanheimo, N.; Hoeberichts, F.A.; Muhlenbock, P.; Brosche, M.; Van Breusegem, F.; Kangasjarvi, J. Spreading the news: Subcellular and organellar reactive oxygen species production and signalling. J. Exp. Bot. 2016, 67, 3831-3844. [CrossRef] [PubMed]

97. Nieves-Cordones, M.; López-Delacalle, M.; Ródenas, R.; Martínez, V.; Rubio, F.; Rivero, R.M. Critical responses to nutrient deprivation: A comprehensive review on the role of ROS and RNS. Environ. Exp. Bot. 2019, 161, 74-85. [CrossRef]

98. Jung, J.Y.; Shin, R.; Schachtman, D.P. Ethylene mediates response and tolerance to potassium deprivation in Arabidopsis. Plant Cell 2009, 21, 607-621. [CrossRef]

99. de Bang, T.C.; Husted, S.; Laursen, K.H.; Persson, D.P.; Schjoerring, J.K. The molecular-physiological functions of mineral macronutrients and their consequences for deficiency symptoms in plants. New Phytol. 2021, 229, 2446-2469. [CrossRef]

100. Kim, M.J.; Ciani, S.; Schachtman, D.P.A. peroxidase contributes to ROS production during Arabidopsis root response to potassium deficiency. Mol. Plant 2010, 3, 420-427. [CrossRef]

101. Valderrama, R.; Corpas, F.J.; Carreras, A.; Gómez-Rodríguez, M.V.; Chaki, M.; Pedrajas, J.R.; Fernández-Ocaña, A.; del Río, L.A.; Barroso, J.B. The dehydrogenase-mediated recycling of NADPH is a key antioxidant system against salt-induced oxidative stress in olive plants. Plant Cell Environ. 2006, 29, 1449-1459. [CrossRef]

102. Signorelli, S.; Corpas, F.J.; Borsani, O.; Barroso, J.B.; Monza, J. Water stress induces a differential and spatially distributed nitro-oxidative stress response in roots and leaves of Lotus japonicus. Plant Sci. 2013, 201, 137-146. [CrossRef]

103. Airaki, M.; Leterrier, M.; Mateos, R.M.; Valderrama, R.; Chaki, M.; Barroso, J.B.; Del Río, L.A.; Palma, J.M.; Corpas, F.J. Metabolism of reactive oxygen species and reactive nitrogen species in pepper (Capsicum annuum L.) plants under low temperature stress. Plant Cell Environ. 2012, 35, 281-295. [CrossRef]

104. Leterrier, M.; Barroso, J.B.; Valderrama, R.; Begara-Morales, J.C.; Sánchez-Calvo, B.; Chaki, M.; Luque, F.; Viñegla, B.; Palma, J.M.; Corpas, F.J. Peroxisomal NADP-isocitrate dehydrogenase is required for Arabidopsis stomatal movement. Protoplasma 2016, 253, 403-415. [CrossRef]

105. Manai, J.; Gouia, H.; Corpas, F.J. Redox and nitric oxide homeostasis are affected in tomato (Solanum lycopersicum) roots under salinity-induced oxidative stress. J. Plant Physiol. 2014, 171, 1028-1035. [CrossRef]

106. Bouthour, D.; Kalai, T.; Chaffei, H.C.; Gouia, H.; Corpas, F.J. Differential response of NADP-dehydrogenases and carbon metabolism in leaves and roots of two durum wheat (Triticum durum Desf.) cultivars (Karim and Azizi) with different sensitivities to salt stress. J. Plant Physiol. 2015, 179, 56-63. [CrossRef]

107. Li, L.Q.; Liu, L.; Zhuo, W.; Chen, Q.; Hu, S.; Peng, S.; Wang, X.Y.; Lu, Y.F.; Lu, L.M. Physiological and quantitative proteomic analyses unraveling potassium deficiency stress response in alligator weed (Alternanthera philoxeroides L.) root. Plant Mol. Biol. 2018, 97, 265-278. [CrossRef] 